\title{
EVALUATION OF Pleurotus ostreatus BASIDIOMES PRODUCTION ON Pinus SAWDUST AND OTHER AGRICULTURAL AND FORESTRY WASTES FROM PATAGONIA, ARGENTINA
}

\author{
Maximiliano Rugolo ${ }^{1,2,}$, Bernardo Lechner ${ }^{1,3}$, Romina Mansilla $^{4}$, Gerardo Mata $^{5}$, Mario Rajchenberg ${ }^{1,2}$
}

\begin{abstract}
The basidiomes production of two strains of Pleurotus ostreatus (one native from Patagonia, Argentina, isolated from the conifer Araucaria araucana and the other one a commercial strain) grown in different agricultural and forestry wastes was studied. The ability of the native strain generates interest to know its degradative capabilities for its use with conifer waste from the regional forest industry, which is dominated by the use of exotic Pinus species. In addition, white poplar (Populus alba), southern beech (Nothofagus pumilio), wheatgrass (Thinopyrum ponticum) and residues from beer brewing were also explored as substrates. The native strain showed better productivity of basidiomes with a biological efficiency of $17,86 \% \pm 3,74 \%$ on pine wood shavings in comparison with the commercial strain used as control. The best substrates were poplar and wheatgrass with biological efficiency between $35,28 \%$ to $88,5 \%$ and $27,84 \%$ to $84,01 \%$, respectively. Supplemented substrates showed better productivity than those without supplement. The low biological efficiency on pine could be attributed to the aromatic compounds contents because, in growth test, the diameter of the fungal colony was affected negatively by the addition of pine resin volatiles, mainly with $\alpha$-limonene and $\delta$-3-carene. In spite of the low biological efficiency, promising inter-breeding or hybrids generation could improve yields in future assays.
\end{abstract}

Keywords: Edible mushroom, pine, sawdust, spent beer grain, wood wastes.

\section{INTRODUCTION}

Leftover agricultural and forest material can be used for edible mushroom production. The accumulation of lignocellulosic residues from cultivated areas is usually a problem because they generate large amounts of biomass that are disposed of by burning in fields (El-Haggar 2007) can be toxic. This modifies the phosporous content in the soil, generating water quality issues such as excess nutrient and sodium concentrations from leachates. Moreover, it changes $\mathrm{pH}$ in soil for some chemical compounds like phenols (Bonanomi et al. 2006a), where it may be harmful for beneficial microbes and pollinators affecting growth of some crops (Ramírez-García et al. 2019) or can be a source of pathogenic organisms (Bonanomi et al. 2006b). However, all these waste products constitute a huge source of energy that could be exploited by xylophagous fungi, which use peroxidases and $\mathrm{Cu}$-dependent laccases in the case of white-rot fungi and iron (Fenton reaction) in the case of brown-rot fungi, for degradation of aromatic chemical compounds (Kubecik 2013). White-rot fungi such as Pleurotus ostreatus are capable of degrading lignin until its complete mineralization due to the extracellular enzymatic groups they secrete (Chang and Miles 2004), such as ligninperoxidases, manganeseperoxidases and laccases. Ligninolytic enzyme production with emphasis in the induction of laccase, has been studied in other genera of white rot fungi as Trametes (Hess et al.2002) and Ganorderma (Kuhar and Papinutti 2014) due to its efficiency as lignin degraders, using metals such us copper.

\footnotetext{
${ }^{1}$ National Scientific and Technical Research Council (CONICET). Buenos Aires, Argentina.

${ }^{2}$ Patagonian Andes Forest Research and Extension Centre (CIEFAP), Esquel, Chubut, Argentina.

${ }^{3}$ Institute of Mycology and Botany (INMIBO), DBBE, Faculty of Exact and Natural Sciences, University of Buenos Aires, Buenos

Aires, Argentina.

${ }^{4}$ Austral Center for Scientific Research (CADIC), Tierra del Fuego, Argentina.

${ }^{5}$ Institute of Ecology (INECOL) Xalapa, México.
}

"Corresponding author: maxirugolo@gmail.com

Received: 29.01.2020 Accepted: 04.07.2020 
Pleurotus ostreatus is worldwide cultivated since many years. In Argentina, it has been cultivated for more than 30 years, using principally wheat straw with annual production (Lechner and Albertó 2011). In the Río Negro valley and Neuquén (Patagonia), it is cultivated on poplar logs in autumn and spring (Albertó et al. 2010). The productive yields of $P$. ostreatus depend on the substrate's degradation and the nutrient content (carbon, nitrogen and phosphorus). Generally, commercial cultivation is made with wheat straw or Salix sp. and Populus sp. sawdust because they are abundant, show shorter growing period, high productivity and also, in the case of straw, allows a process of pasteurization at $60^{\circ} \mathrm{C}$ (Yildiz et al. 2002, Lechner and Albertó 2011).

There are only few records of Pleurotus ostreatus cultivation on resinous substrates, in spite of the interest to use pine sawmills wastes around the world. This is due to usually contain a high concentration of wood extractives or pitch deposits (Croan 2003). Schmidt (1986) obtained basidiomes of P. ostreatus in outdoors cultures on softwoods chips of Norway spruce (Picea abies) and Scots pine (Pinus sylvestris) but he did not report yields or productivity data.

Agricultural production in the Patagonian Andean region generates large amounts of wastes. With the increase of beer brewing and wine production, spent beer grains and grape vines and stalks are very abundant and have low cost. These residues have already been tested as substrates or supplements (Wang et al. 2001, Lara et al. 2002, Lechner and Albertó 2002, Gregori et al. 2008). The exploitation of southern beech (Nothofagus pumilio) wood to manufacture products (Bava and López Bernal 2006) also generates sawdust or wood shavings. However, the main waste from the northwest Patagonian Andean region are chips, sawdust and shavings from pine plantations, and these also could be used for the cultivation of this mushroom.

Pleurotus ostreatus has been found in Argentina fruiting naturally on deciduous trees, mainly from the genera Populus and Salix, especially on fallen trunks or very old standing trees (Lechner et al. 2004). It has also been registered and isolated on the native conifer Araucaria araucana (Lechner et al. 2002), producing basidiomes and rots. This tree species presents a strong antimicrobial activity, for which reason few species of Basidiomycota and Ascomycota have been reported so far (Céspedes et al. 2005). The oleoresin complex (mixture of resins and essential oils) is the primary defense system in conifers and is the main mechanism of resistance against the invasion of insects and pathogens (Paine and Hanlon 1994). Pleurotus ostreatus strains growing on Araucaria araucana generate interest to know its potential degradative abilities for their eventual use with conifer wastes from the regional Pinus forest industry, mainly dominated by Pinus ponderosa.

The aim of this work is to explore the ability of a native strain of $P$. ostreatus to grow, degrade and develop basidiomes on substrates generated from conifer debris of the Patagonian forest industry. In addition, we explore poplar (Populus), southern beech (N. pumilio), wheatgrass (Thinopyrum) and residues from beer brewing as potential substrates.

\section{MATERIALS AND METHODS}

\section{Fungal strains and culture conditions}

Two strains of Pleurotus ostreatus (Jacq. ex Fr.) P. Kumm. (Agaricales, Basidiomycota) were used: 1) $P$. ostreatus CIEFAPcc 619 (Fungal Collection of the Centro de Investigación y Extensión Forestal Andino Patagónico - CIEFAP): Argentina, Neuquén, Pehuenia, $1 \mathrm{~km}$ from Pulmarí gate to Lanín National Park, on Araucaria araucana tree, leg. M. Rajchenberg 12517 and M. Rugolo, 2 May 2013 . 2) P. ostreatus strain CIEFAPcc 129; commercial strain from Italy.

Strains were incubated at $23{ }^{\circ} \mathrm{C}$ and kept at $4{ }^{\circ} \mathrm{C}$ on malt-extract (ME) agar $(1,2 \%$ malt extract, $1 \%$ glucose, and $2 \%$ agar) until use.

\section{Spawn production}

Spawn was produced in $350 \mathrm{ml}$ glass jars filled with boiled oat grains (Avena sativa) and $1 \%(\mathrm{w} / \mathrm{w})$ $\mathrm{CaCO}_{3}$. Jars were sterilized for $1,5 \mathrm{~h}$ at $121^{\circ} \mathrm{C}$, cooled and inoculated with a $1 \mathrm{~cm}$ diameter plug of mycelium and then they were incubated at $23^{\circ} \mathrm{C}$ in the dark for $20 \mathrm{~d}$, with periodical shaking (once every three days). 


\section{Substrate preparation}

Polypropylene bags of $25 \mathrm{~cm} \times 15 \mathrm{~cm}$ were filled with $100 \mathrm{~g}$ (dry weight) of substrate: wood shavings (1 $\mathrm{cm} \times 1 \mathrm{~cm}$ ) of the regional residues as base substrate: Pinus ponderosa (pine), Populus alba (white poplar), Nothofagus pumilio (southern beech), and Thinopyrum ponticum (wheatgrass) supplemented with spent beer grain (malted barley) at $40 \% \mathrm{w} / \mathrm{w}$. Humidity was adjusted $(\mathrm{w} / \mathrm{w})$ to $75 \%$. Bags were closed with cotton plugs held by polyvinyl chloride (PVC) cylinders and sterilized in autoclave at $121{ }^{\circ} \mathrm{C}$ for $1,5 \mathrm{~h}$ (Zadražil 1978). The control was made with pine wood shavings (Pinus ponderosa) residues without supplement.

\section{Inoculation and basidiomes induction}

After cooling, bags were inoculated with $5 \%$ (wet weight) of spawn, and were incubated at $23{ }^{\circ} \mathrm{C}$ in the dark until total substrate colonization (25-35 days).

After total colonization by the mycelium, polypropylene bags were opened with small cuts and transferred to the basidiome production rooms. Cropping conditions to induce basidiome formation were $18{ }^{\circ} \mathrm{C} \pm 2{ }^{\circ} \mathrm{C}, 12$ $\mathrm{h}$ light/12 h dark photoperiod (2000 lux of fluorescent light), $75 \%$ to $85 \%$ humidity levels and watering by automatic spray provided for 2 min, 3 times every day (modified from Albertó 2008).

Up to three flushes were harvested during the cropping period (45 days between the induction day and the last harvest) in the different substrates. Mature basidiomes ( $80 \%$ of expanded pileus) were collected manually. Biological efficiency (BE), calculated as the percentage ratio of fresh mushrooms weight over the dry weight of the substrate, was used to test the suitability of the substrates (Rugolo et al. 2016).

\section{Fiber analysis}

A representative portion of raw materials and residual substrates were dried, ground ( $1 \mathrm{~mm}$ grid size) and pooled. Samples were studied for their fiber fractions (hemicellulose, cellulose and lignin), extractives (gums, tannins, resins and latexes among others) and mineral composition (carbon, nitrogen and phosphorous). Fibers analyses were done by the Van Soest acid detergent fiber method (Van Soest 1963) employing an automated Fiber Analyzer (Ankom A2000) with filter bags F57 and mineral composition was obtained using inducted coupled plasma mass spectrometry.

\section{Volatile compounds effects on growth}

The effects of individual volatile compounds on the growth of the native $P$. ostreatus strain were determinated using a modification of López et al. (2013) methods. Five volatile compounds commonly found in Pinus sp. were assayed, including $\alpha$-limonene, 4 -carvomenthenol, $\delta$-3-carene, $\beta$-citronellol, and $\rho$-cymen- 8 -ol purchased from Pherotech International Inc. (Delta, BC, Canada). Malt Extract Agar (MEA) medium was used as control and MEA medium with $0,1 \mathrm{mM}$ of copper $\left(\mathrm{CuSO}_{4}\right.$ Sigma-Aldrich) was used as promotor (modified from Kuhar and Papinutti 2014).

\section{Statistical treatments}

For basidiome production, each treatment consisted of ten replicates. Analysis of variance (ANOVA) was used with BEs measurements and significant differences between treatments were compared by Tukey's test at $5 \%$ level probability. Kruskal Wallis non parametric method was used when normality (Shapiro Wilks) or homogeneity (Levene) did not comply. Statistical treatments were tested with InfoStat software (InfoStat 2017).

\section{RESULTS}

\section{Waste nutritional composition and basidiome production}

The values for carbon, nitrogen and phosphorus of different local agricultural and forest waste by-products are shown in Table 1. The $\mathrm{C}, \mathrm{N}$ and $\mathrm{P}$ values were similar between the wastes of beer production (spent beer grain) and the industrial wheat bran (traditionally used as supplement), indicating that this residue is an economic alternative for the formulation of substrates, contributing $\mathrm{N}$ and $\mathrm{P}$ principally (Table 1). In the case of 
base substrate, $\mathrm{C}$ content was similar in all materials, the $\mathrm{N}$ content was higher in pine sawdust $(0,264 \%)$ and wheatgrass $(0,208 \%)$ in comparison with poplar $(0,138 \%)$ and southern beech sawdust $(0,131 \%)$; whereas $P$ was higher in wheatgrass and poplar content.

Table 1: Nutritional composition $(\mathrm{C}, \mathrm{N}$ and $\mathrm{P})$ of different local agricultural waste by-products.

\begin{tabular}{|c|c|c|c|}
\hline Substrate & Carbon (\%) & Nitrogen (\%) & Phosphorus (mg/kg) \\
\hline White poplar sawdust & 45,60 & 0,138 & 176 \\
\hline Southern beech sawdust & 47,53 & 0,131 & 88 \\
\hline Pine sawdust & 47,40 & 0,264 & 68 \\
\hline Wheatgrass & 43,98 & 0,208 & 170 \\
\hline Spent beer grain & 46,46 & 2,898 & 5190 \\
\hline Wheat bran (extra regional) & 42,90 & 2,702 & 5892 \\
\hline
\end{tabular}

The commercial strain of Pleurotus ostreatus CIEFAPcc 129 was more productive than CIEFAPcc 619 native strain in white poplar, wheatgrass, and southern beech substrates $(\mathrm{p}<0,05)$. Biological efficiency was over $80 \%$ with poplar $(88,5 \% \pm 12,9 \%)$ and with wheatgrass $(84,01 \% \pm 9,32 \%)$, and close to $30 \%$ with southern beech $(29,92 \% \pm 6,96 \%)$, while the native strain produced BE close to $40 \%$ in white poplar $(35,28 \% \pm 21,9$ $\%)$ and in wheatgrass $(27,84 \% \pm 3,98 \%)$ and close to $10 \%$ in southern beech $(7,56 \% \pm 2,05 \%)$ (Figure 1 ).

However, in the treatment with pine as a base substrate, the strain with the highest production was the native CIEFAPcc 619 , with a BE of $17,86 \% \pm 3,74 \%$ in comparison with CIEFAPcc 129 which achieved a BE of $7,15 \% \pm 3,14 \%(p<0,05)$ (Figure 1). On the other hand, in the substrate without supplement, the mycelium grew fully in 30-40 days, but there was not development of basidiomes.

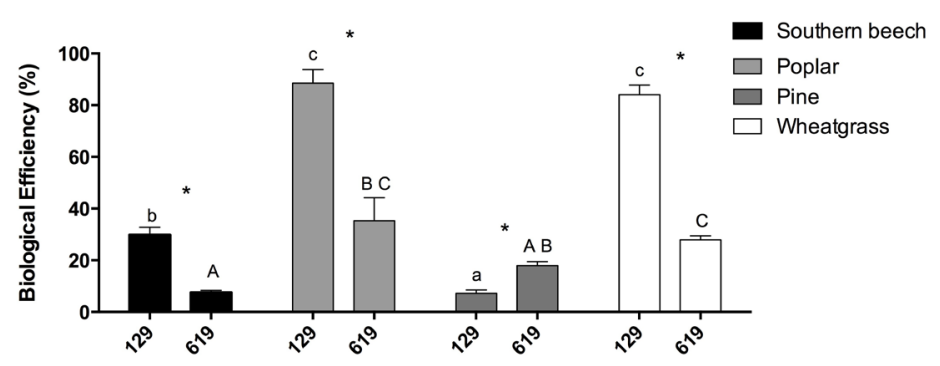

Figure 1: Biological efficiency of Pleurotus ostreatus cultivated on different local substrates

Different capital letters indicate significant differences between the substrates used with CIEFAPcc 619 strain $(p<0,05)$. Different lowercase letters indicate significant differences between the substrates used with CIEFAPcc 129 strain $(p<0,05)$. Asterisks indicate significant differences between strains CIEFAPcc 129 and CIEFAPcc 619 for each substrate $(\mathrm{p}<0,05)$.

\section{Fiber analysis of the substrates after crop period}

The proportional of lignin, cellulose and hemicellulose was lower after degradation by both strains in white poplar, while in southern beech and pine the degradation was greater on lignin. In wheatgrass, the degradation was mainly on cellulose. In all substrates, the percentage of extractives (gums, tannins, resins and latexes among others) increased after fungal degradation (Figure 2). 


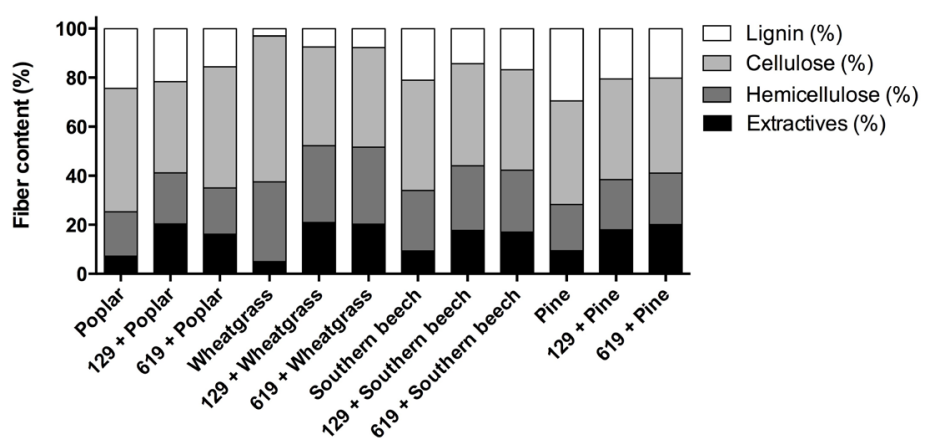

Figure 2: Fiber analysis of lignin, cellulose, hemicellulose and extractives (gums, tannins, resins and latexes) of different substrates after $P$. ostreatus degradation. The control was the substrate without fungal colonization.

\section{Volatile compounds effects}

The diameter of the fungal colony was negatively affected by the addition of resin volatiles. The treatment with copper $\left(\mathrm{CuSO}_{4}, 41,25 \mathrm{~mm} \pm 0,5 \mathrm{~mm}\right)$ in the evaluated concentration did not show differences with the MEA medium control $(40,91 \mathrm{~mm} \pm 0,14 \mathrm{~mm})$ after 9 days. However, it was lower in treatments with $\alpha$-limonene $(35,00 \mathrm{~mm} \pm 3,04 \mathrm{~mm})$ and $\delta$-3-carene $(30,25 \mathrm{~mm} \pm 6,72 \mathrm{~mm})$; and null with 4-carvomenthenol, $\beta$-citronellol and $\rho$-cymen-8-ol (Figure 3).

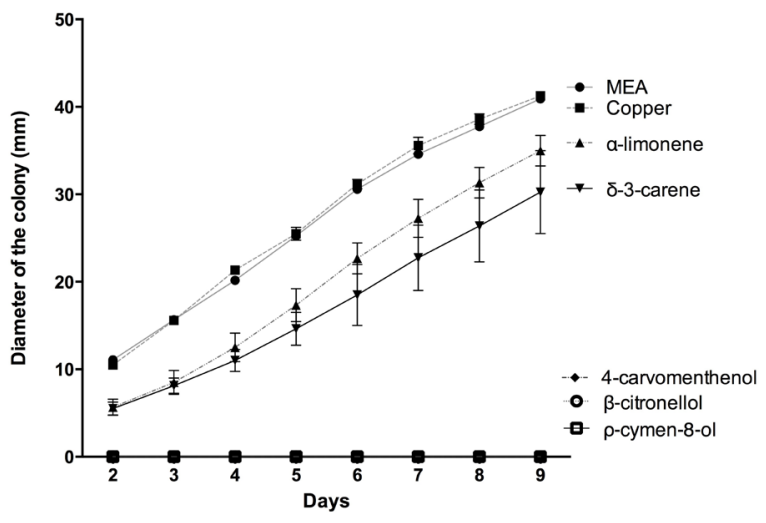

Figure 3: Mycelium growth in MEA medium with copper $\left(\mathrm{CuSO}_{4}\right)$ and volatile compounds addition.

\section{Discussion}

The studied residues of agricultural and forest wastes from Patagonia were found to be useful for the production of Pleurotus ostreatus basidiomes. The highest yields were obtained with a commercial strain, except in pine substrate, where the native strain showed better mycelium growth and productive yields. When pine was used, the BEs reached by the native strain was $30 \%$ higher than the commercial strain used, as expected. Although these BEs were less than $50 \%$, minimum value suggested for a profitable production (Patra and Pani 1995), the use of sawdust and shavings of the most commonly used wood in Patagonia, would allow the generation of high value food from a high available waste. This result allows to propose new assays with some additional additive to fine-tune the substrate and obtain higher yields, or look for promising crosses to take advantage of the growth capacity in resinous substrates of the local strains. Previously, different Mexican strains obtained for monosporic inter-breeding of $P$. ostreatus were cultivated in pine wood shaving, with biological efficiencies between 27,98 \% to 53,53 \% (Pérez Merlo and Mata 2005). In the present work, the best substrate to both strains was white poplar sawdust. However, the disposition of poplar wastes were lower than 
the others. Regarding the substrate, in general, willow shavings or wheat straw were the best substrates for the cultivation of Pleurotus (Lechner and Albertó 2011) in comparison with hardwoods or resinous woods. Wheat straw requires a shorter period of fermentation and fewer food supplements because it contains high cellulose content, $39 \%$ to $51 \%$ (Yildiz et al. 2002).

The residues of the brewing production were suitable supplements for edible mushrooms production and could easily be replaced by the traditional wheat bran. In addition to the yields obtained with this supplement, the analysis of the nutrient content shows that the spent beer grain presented 2,89\% of nitrogen against 2,70 $\%$ of wheat bran and $5190 \mathrm{mg} / \mathrm{kg}$ against $5892 \mathrm{mg} / \mathrm{kg}$ of phosphorus. White poplar sawdust and wheatgrass seems to be the best option for the production of $P$. ostreatus in Patagonia. For both mycelium growth and basidiomes, development on lignin cellulose material within $\mathrm{C} / \mathrm{N}$ value of 50/1 are sufficient (Block et al. 1958). Straw substrate has proved in practice to be the simplest nutrient base (Zadražil 1978) with low percentage of lignin content and nitrogen level (Philippoussis et al. 2001). Addition of the supplements with basal substrate has been a common practice to shorten the crop period and enhance the yield, nutritional and medicinal values (Naraian et al. 2016). In our work, when supplemented substrates were rich in $\mathrm{N}$ content, colonization was greater and more intense, and this positive relation is consistent with previous reports indicating the positive effect of nitrogen (lower C:N ratio) during Pleurotus ostreatus cultivation (Bellettini et al. 2016). Moreover, the final constitution of spend substrate is altered by the removal of nutrients by Pleurotus mycelium. In this process $\mathrm{N}, \mathrm{K}$ and $\mathrm{P}$ macroelements decreased because they are used for basidiomes development (aminoacids, vitamins and other biologically active products) (Zadražil 1978).

In the future, we should evaluate the willow chips made from rods, in replacement of poplar, because $\mathrm{Sa}$ lix is more invasive and has a high occurrence in riversides (Datri et al. 2016); moreover, Pleurotus has been found in willow trunks fruiting naturally (Lechner et al. 2004). We could use pruning remains of the poplar trees planted as windbreaker or shavings and sawdust generated in the sawmill processing of this wood because it is important in fruits packaging and furniture manufacturing (García et al. 2017, Jovanovski et al. 2011).

The EBs on wheatgrass, which averaged $80 \%$, showed the excellent aptitude of this material as substrate, being similar to reports on wheat straw (Salmones et al. 2005, Kumari and Achal 2008, Lechner and Albertó 2011, Jaramillo and Albertó 2013, Garuba et al. 2017). This grass could replace the wheat straw traditionally used as cattle forage in the region and with limited availability in comparison with Pampas region (Albertó et al. 2010). Southern beech was not a good substrate to Pleurotus production (BEs < than $30 \%$ ), probably for the recalcitrant compounds present in lignin and extractives fractions (Gallo et al. 2019).

The fiber analysis revealed that strains differed in their degradative action depending on the growth medium. This differential action according to the substrate used was also reported by Postemsky et al. (2017) with Ganoderma lucidum cultivated in wheat straw and sunflower seed husks. Compared with the control substrate in poplar, the cellulose fraction decreases when strain CIEFAPcc 129 acts and the lignin fraction decreases in the case of strain CIEFAPcc 619. The behavior of both strains in wheatgrass showed a marked decrease in cellulose content, and a proportional increase in lignin. When the substrate used was southern beech or pine, both strains degraded lignin principally, decreasing its fraction in relation to cellulose or hemicellulose. This is typical process of a white rot fungus belonging to the type of simultaneous white-rot fungi (Martínez et al. 2005, Kubecik 2013). The lignin percentages in these substrates are a very important fraction that displays an inhibitor role for microbial action, protecting hemicellulose and cellulose from fungal attack (Ruiz-Dueñas and Martínez 2009). The extractives fraction, mainly in pine and southern beech also plays a recalcitrant and toxic role, principally due for the resins (Himejima et al. 1992) and tannins contents (Serrano et al. 2009).

In spite of the low BEs obtained in the pine substrates, we were able to demonstrate that the native strain of Pleurotus ostreatus growing on Araucaria araucana presents an adaptation to the resinous contents in Pinus ponderosa because it presented a better behavior in comparison to the commercial strain used as control. The aromatic fraction compounds could be responsible for the mycelial growth decrease and the low BE obtained when strains were grown in formulations with conifer residues. Precisely, cultures in agar medium showed a growth decrease when they were exposed to different conifer aromatic compounds. This coincided with López et al. (2013), who showed that the growth of the lignivorous fungi Amylostereum areolatum and A. chailletii was adversely affected in the presence of Pinus ponderosa and Pseudotsuga menziesii essential oils. For $A$. areolatum this had a delay in growth of $86,52 \%$ and $85,28 \%$, respectively, and for $A$. chailletii it had a delay of $97,1 \%$ and $92,36 \%$, respectively. However, in the control culture with copper growth was induced, probably due to laccase enzyme induction. This induction by metallic ions has already been demonstrated in numerous works. Studies on Pleurotus showed the induction effect of laccase activity with $\mathrm{CuSO}_{4} 150 \mu \mathrm{M}$ (Palmieri et al. 2000) and similar results were obtained with Coriolus hirsuta (Koroljova-Skorobogat'ko et al. 1998) and 
Neurospora crassa (Schilling et al. 1992). A study with a white-rot Trametes versicolor strain, the optimal copper concentration $\left(\mathrm{CuSO}_{4} .5 \mathrm{H}_{2} \mathrm{O}\right)$ for the highest laccase production was $0,5 \mathrm{mM}$ (Birhanli and Yesidala 2017). In addition, Lorenzo et al. (2006) showed that a slight stimulatory effect of heavy metals on laccase production from $T$. versicolor was observed in the presence of $\mathrm{Ag}^{+}, \mathrm{Cd}^{2+}, \mathrm{Mn}^{2+}$ and $\mathrm{Zn}^{2+}$ whereas the cultures supplemented with copper sulphate $(2 \mathrm{mM})$ showed the highest values, which is about 9-fold higher than that attained in the control. For other white-rot fungi, as Ganoderma lucidum, Kuhar and Papinutti (2014) showed laccase induction with phenolic and metallic inducers (copper, manganese, cadmium, chrome). In this case, $\mathrm{CuSO}_{4} 1 \mathrm{mM}$ appeared to be the best inducer, and the effect becomes more marked in combination with ferulic acid. These results clearly showed the positive effect of copper sulphate as an inducer of laccase activity.

\section{CONCLUSIONS}

A native strain of Pleurotus ostreatus growing on conifer Araucaria araucana had the ability to grow, degrade and develop basidiomes on substrates generated from conifer debris of the regional forest industry. In spite that the aromatic compounds showed growth inhibition, these advances in the cultivation of this edible mushroom on resinous substrates could be optimized to enable the development of large-scale production with higher yields.

\section{ACKNOWLEDGEMENTS}

The authors acknowledge the financial assistance provided from the National Council of Scientific and Technical Research (CONICET) and from Ministerio de Ciencia y Tecnología e Innovación Productiva through Project 2015/1933 (PICT-MinCyT).

\section{REFERENCES}

Albertó, E. 2008. Cultivo intensivo de los hongos comestibles: cómo cultivar champiñones, gírgolas, shiitake y otras especies. Editorial hemisferio sur, Buenos Aires, Argentina. 250 p.

Albertó, E.; Curvetto, N.; Deschamps, J.; González Matute, R.; Lechner, B. 2010. Hongos Silvestres y de Cultivo en Argentina: Historia, regiones y sistemas de producción, hongos silvestres de valor económico, consumo, mercado interno y externo, legislación, oferta tecnológica e investigación y desarrollo. In Hacia un desarrollo sostenible del sistema de producción-consumo de los hongos comestibles y medicinales en Latinoamérica: avances y perspectivas en el siglo XXI, Capítulo 19: 333-358. Martínez-Carrera, D., Curvetto, N., Sobal, M., Morales, P., Mora, V.M. (Eds.). Red Latinoamericana de Hongos Comestibles y Medicinales, Puebla, México. http://ici.unq.edu.ar/ici_tps/tp_ici1/2010\%20Capitulo\%20Albert\%C3\%B3\%20et\%20al.\%20 Argentina\%20110310.pdf

Bava, J.O.; Lopez Bernal, P.M. 2006. Cortas de selección en grupo en bosques de lenga de Tierra del Fuego. Quebracho 13: 77-86. https://www.redalyc.org/pdf/481/48101308.pdf

Bellettini, M.B.; Fiorda, F.A.; Maieves, H.A.; Teixeira, G.L.; Ávila, S.; Hornung, P.S.; Maccari, A.; Ribania, R.H. 2016. Factors affecting mushroom Pleurotus spp. Saudi J Biol Sci 26: 636-646. http://dx.doi.org/10.1016/j.sjbs.2016.12.005

Birhanli, E.; Yesilada, O. 2017. The effect of various inducers and their combinations with copper on laccase production of Trametes versicolor pellets in a repeated-batch process. Turk J Biol 41: 587-599. http://dx.doi.org/10.3906/biy-1608-44

Block, S.; Tsao, G.; Han, L. 1958. Production of mushrooms from sawdust. Agricultural and Food Chemistry 6(12): 923-927.

Bonanomi, G.; Caporaso, S.; Allegrezza, M. 2006b. Short-term effect of nitrogen enrichment, litter 
removal and cutting on a Mediterranean grassland. Acta Oecol 30: 419-425. https://dx.doi.org/10.1016/j.actao.2006.06.007

Bonanomi, G.; Giorgi, V.; Giovanni, D.S.; Neri, D.; Scala, F. 2006a. Olive mill residues affect saprophytic growth and disease incidence of foliar and soilborne plant fungal pathogen. Agr Ecosyst Environ 115: 194-200. https://dx.doi.org/10.1016/j.agee.2006.01.002.

Céspedes, C.L.; Avilab, G.J.; García, A.M.; Becerra, J.; Flores, C.; Aqueveque, P.; Bittner, M.; Hoeneisen, M.; Martínez, M.; Silva, M. 2005. Antifungal and antibacterial activities of Araucaria araucana (Mol.) K. Koch heartwood lignans. Z Naturforsch 61(1-2): 35-43. http://dx.doi.org/10.1515/znc-2006-1-207

Chang, S.T.; Miles, P.G. 2004. Mushrooms Cultivation, Nutritional value, Medicinal effect, and Enviromental Impact. CRC Press: Boca Raton, United States of America. 451p.

Croan, S.C. 2003. Utilization of treated conifer wood chips by Pleurotus (Fr.) P. Karst. species for cultivating mushrooms. Mushrooms International 91: 4-7. https://www.fpl.fs.fed.us/documnts/pdf2003/croan03a.pdf

Datri, L.A.; Faggi, A.M.; Gallo, L.A. 2016. Entre el orden y el caos: invasiones con dinámicas no lineales de sauces y álamos en el norte de la Patagonia. Revista de la Asociación Argentina de Ecología de Paisajes 6(1):12-22.

El-Haggar, S.M. 2007. Sustainability of Agricultural and Rural Waste Management. In Sustainable Industrial Design and Waste Management. Chapter 7: 223-260. Elsevier. http://dx.doi.org/10.1016/b978-012373623-9/50009-5

Gallo, A.L.; Moretto, A.; López Bernal, P.; Greslebin, A. 2019. Characterization and decomposition of Nothofagus pumilio fine woody material. Can $J$ For Res 49(6): 715-720. https://dx.doi.org/10.1139/cjfr-2018-0185

García, J.; Aguerre, M.; Denegri, G.A.; Acciaresi, G. 2017. Aplicación del sistema de valor a la planificación del desarrollo de las cadenas forestoindustriales de álamos ubicadas en el norte de la Patagonia argentina. DELOS 10(29): 1-16. http://www.eumed.net/rev/delos/29/index.html

Garuba, T.; Abdulkareem, K.A.; Ibrahim, I.A.; Oyebamiji, O.I.; Shoyoye, O.A.; Ajibade, T.D. 2017. Influence of substrates on the nutritional quality of Pleurotus pulmonarius and Pleurotus ostreatus. Ceylon J Sci 46(1): 67-74. https://dx.doi.org/10.4038/cjs.v46i1.7419

Gregori, A.; Švagelj, M.; Pahor, B.; Berovič, M.; Pohleven, F. 2008. The use of spent brewery grains for Pleurotus ostreatus cultivation and enzyme production. New Biotechnol 25(2-3): 157-161. https://dx.doi.org/10.1016/j.nbt.2008.08.003

Hess, J.; Leitner, C.; Galhaup, C.; Kulbe, K.D.; Hinterstoisser, B.; Steinwender, M.; Haltrich, D. 2002. Enhanced formation of extracellular laccase activity by the white-rot fungus Trametes multicolor. Appl Biochem Biotechnol 98: 229-241. http://dx.doi.org/10.1385/abab:98-100:1-9:229

Himejima, M.; Hobson, K.R.; Otsuka, T.; Wood, D.L.; Kubo, I. 1992. Antimicrobial terpenes from oleoresin of ponderosa pine tree Pinus ponderosa: A defense mechanism against microbial invasion. $J$ Chem Ecol 18: 1809-1818. http://dx.doi.org/ 10.1007/BF02751105

InfoStat. 2017. Version 2017. Grupo InfoStat, FCA, Universidad Nacional de Córdoba, Córdoba, Argentina. http://www.infostat.com.ar

Jaramillo Mejía, S.; Albertó, E. 2013. Heat treatment of wheat straw by immersion in hot water decreases mushroom yield in Pleurotus ostreatus. Rev Iberoam Micol 30(2): 125-129. http://dx.doi.org/10.1016/j.riam.2012.11.004

Jovanovski, A.; Robles, G.; Davel, M. 2011. Propiedades físicas de la madera de Populus spp. proveniente de cortinas forestales plantadas en Esquel, Chubut, Argentina. Trabajo Técnico. In Actas del Tercer Congreso Internacional de Salicáceas en Argentina. Neuquén, Argentina. 6 p. https://docs.google.com/ viewer?a=v\&pid=sites\&srcid=ZGVmYXVsdGRvbWFpbnx0cmFiYWpvc3RlY25pY29zanMyMDExfGd4O- 


\section{jYyMTg2M2NjYTIyNDgxNWQ}

Koroljova-Skorobogat'ko, O.V.; Stepanova, E.V.; Gavrilova, V.P.; Morozova, O.V.; Lubimova, N.V.; Dzchafarova, A.N.; Jaropolov, A.I.; Makower, A. 1998. Purification and characterization of the constitutive form of laccase from the basidiomycete Coriolus hirsutus and effect of inducers on laccase synthesis. Biotechnol Appl Biochem 28(1): 47-54.

Kubecik, C.P. 2013. Fungi and lignocellulosic biomass. John Wiley \& Sons, Inc: Iowa, United States of America. 304p.

Kuhar, F.; Papinutti, L. 2014. Optimization of laccase production by two strains of Ganoderma lucidum using phenolic and metallic inducers. Rev Argent Microbiol 46(2): 144-149. https://dx.doi.org/10.1016/S0325-7541(14)70063-X

Kumari, D.; Achal, V. 2008. Effect of different substrates on the production and non-enzymatic antioxidant activity of Pleurotus ostreatus (Oyster mushroom). Life Sci 5(3): 73-76. http://www.lifesciencesite.com/ 1sj/life0503/12 life0503 7376 Effect.pdf

Lara, M.; Arias, A.; Villaseñor, L. 2002. Cultivation of Pleurotus ostreatus and P. pulmonarius on spent brewer's grain and tequila maguey bagasse. In Proceedings IV International Conference on Mushroom Biology and Mushroom Products. Cuernavaca, México. 323-330 pp.

Lechner, B.E.; Albertó, E. 2002. Empleo de desechos húmedos de malta cervecera para la producción de Pleurotus ostreatus. In IV Congreso Latinoamericano de Micología. Asociación Latinoamericana de Micología. Xalapa, Veracruz, México.

Lechner, B.E.; Petersen, R.; Rajchenberg, M.; Albertó E. 2002. Presence of Pleurotus ostreatus in Patagonia, Argentina. Rev Iberoam Micol 19(2): 111-114. http://www.reviberoammicol.com/2002-19/111114.pdf

Lechner, B.E.; Wright, J.E.; Albertó, E. 2004. The genus Pleurotus in Argentina. Mycologia 96(4): 845858. https://dx.doi.org/10.1080/15572536.2005.11832931

Lechner, B.E.; Albertó, E. 2011. Search for new naturally occurring strains of Pleurotus to improve yields. Pleurotus albidus as a novel proposed species for mushroom production. Rev Iberoam Micol 28(4): 148-154. http://dx.doi.org/10.1016/j.riam.2010.12.001

López, S.N.; Greslebin, A.G.; González, S.B.; Pildain, M.B. 2013. Efecto del potencial agua y de la defensa primaria del hospedante sobre el crecimiento de Amylostereum areolatum y A. chailletii, simbiontes fúngicos de los sirícidos, y estudio de la micobiota asociada a la madera de coníferas en Patagonia, Argentina. Bosque 34(2): 161-171. http://dx.doi.org/10.4067/S0717-92002013000200005

Lorenzo, M.; Moldes, D.; Sanromán, M.A. 2006. Effect of heavy metals on the production of several laccase isoenzymes by Trametes versicolor and on their ability to decolorize dyes. Chemosphere 63(6): 912917. http://dx.doi.org/10.1016/j.chemosphere.2005.09.046

Martínez, A.T.; Speranza, M.; Ruiz-Dueñas, F.; Ferreira, N.P.; Camarero, S.; Guillen, F.; Martínez, M.J.; Gutiérrez, A.; del Río, J.C. 2005. Biodegradation of lignocellulosics: Microbial, chemical, and enzymatic aspects of the fungal attack of lignin. Int Microbiol 8(3): 195-204.

Naraian, R.; Singh, M.P.; Ram, S. 2016. Supplementation of basal substrate to boost up substrate strength and oyster mushroom yield: An overview of substrates and supplements. International Journal of Current Microbiology and Applied Sciences 5(5): 543-553. http://dx.doi.org/ 10.20546/ijcmas.2016.505.056

Palmieri, G.; Giardina, P.; Bianco, C.; Fontanella, B.; Sannia, G. 2000. Copper induction of laccase isoenzymes in the ligninolytic fungus Pleurotus ostretatus. Appl Environ Microb 66(3): 920-924. http://dx.doi.org/10.1128/aem.66.3.920-924.2000

Paine, T.D.; Hanlon, C.C. 1994. Influence of oleoresin constituents from Pinus ponderosa and Pinus jeffreyi on the growth of the mycangial fungi from Dendroctonus ponderosae and Dendroctonus brevicomis. $J$ Chem Ecol 20(10): 2551-2563. http://dx.doi.org/10.1007/BF02036191 
Patra, A.K.; Pani, B.K. 1995. Evaluation of banana leaf as a new alternative substrate to paddy straw for oyster mushroom cultivation. Journal of Phytological Research 8(2): 145-148. http://www.jphytolres.org/system/files/old_papers/9_15.pdf

Pérez Merlo, R.; Mata, G. 2005. Cultivo y selección de cepas de Pleurotus ostreatus y P. pulmonarius en viruta de pino: obtención de nuevas cepas y evaluación de su producción. Revista Mexicana de Micología 20: 53-59. https://www.redalyc.org/pdf/883/88302009.pdf

Philippoussis, A.N.; Zervakis, G.I.; Diamantopoulou, P.A. 2001. Bioconversion of agricultural lignocellulosic wastes through the cultivation of the edible mushrooms Agrocybe aegerita, Volvariella volvacea and Pleurotus spp. World J Microb Biot 17(2): 191-200. http://dx.doi.org/ 10.1023/A:1016685530312

Postemsky, P.D.; Bidegain, M.A; González-Matute, R.; Figlas, N.D.; Cubitto, M.A. 2017. Pilot-scale bioconversion of rice and sunflower agro-residues into medicinal mushrooms and laccase enzymes through solid-state fermentation with Ganoderma lucidum. Bioresour Technol 231: 85-93. http://dx.doi.org/10.1016/j.biortech.2017.01.064

Ramírez-García, R.; Gohil, N.; Singh, V. 2019. Recent Advances, Challenges, and Opportunities in Bioremediation of Hazardous Materials. In Phytomanagement of Polluted Sites. Chapter 21: 517-568. Pandey, V. C.; Bauddh, K. (Eds). Elsevier. http://dx.doi.org/10.1016/b978-0-12-813912-7.00021-1

Rugolo, M.; Levin, L.; Lechner, B.E. 2016. Flammulina velutipes: an option for alperujo use. Rev Iberoam Micol 33(4): 242-247. http://dx.doi.org/10.1016/j.riam.2015.12.001

Ruiz-Dueñas, F.J.; Martinez, A.T. 2009. Microbial degradation of lignin: how a bulky recalcitrant polymer is efficiently recycled in nature and how we can take advantage of this. Microbial Biotechnology 2(2): 164-177. http://dx.doi.org/ 10.1111/j.1751-7915.2008.00078.x.

Salmones, D.; Mata, G.; Waliszewski, K.N. 2005. Comparative culturing of Pleurotus spp. on coffee pulp and wheat straw: biomass production and substrate biodegradation. Bioresour Technol 96(5): 537-544. https://doi.org/10.1016/j.biortech.2004.06.019

Serrano, J.; Puupponen-Pimiä, R.; Dauer, A.; Aura, A.M.; Saura-Calixto, F. 2009. Tannins: Current knowledge of food sources, intake, bioavailability and biological effects. Mol Nutr Food Res 53: 310-329. http://dx.doi.org/10.1002/mnfr.200900039

Schilling, B.C.; Linden, R.M.; Kupper, U.; Lerch, K. 1992. Expression of Neurospora crassa laccase under the control of the copper-inducible metallothionein-promoter. Curr Genet 22(3): 197-203. http://dx.doi.org/10.1007/bf00351726

Schmidt, O. 1986. Experiments with mushroom cultivation on wood waste. Plant Research and Development 24: 85-92.

Van Soest, P.J. 1963. Use of detergents in the analysis of fibrous feeds. A rapid method for the determination of fiber and lignin. Journal of the Association of Official Agricultural Chemists 46(5): 829-835.

Wang, D.; Sakoda, A.; Suzuki, M. 2001. Biological efficiency and nutritional value of Pleurotus ostreatus cultivated on spent beer grain. Bioresour Technol 78(3): 293-300. http://dx.doi.org/10.1016/S0960-8524(01)00002-5

Yildiz, S.; Yildiz, Ü.C.; Gezer, E.D.; Temiz, A. 2002. Some lignocellulosic wastes used as raw material in cultivation of the Pleurotus ostreatus culture mushroom. Process Biochem 38(3): 301-306. http://dx.doi.org/10.1016/s0032-9592(02)00040-7

Zadražil, F. 1978. Cultivation of Pleurotus. In The Biology and Cultivation of Edible Mushrooms 521557. http://dx.doi.org/10.1016/b978-0-12-168050-3.50031-1 